\title{
F3:6 Generasyonunda Pamuk (Gossypium hirsutum L.) Döl Sıralarının Tam ve Kısıtı Sulama Koșullarında Verim ve Lif Kalite Özelliklerinin Belirlenmesi
}

\section{Bahar ULU'(D), Hüseyin BAȘAL ${ }^{* 2}$ [D}

\author{
I Adnan Menderes Üniversitesi, Fen Bilimleri Enstitüsü, Tarla Bitkileri Anabilim Dalı, Aydın.
}

2 Adnan Menderes Üniversitesi, Ziraat Fakültesi, Tarla Bitkileri Bölümü, Aydın.

Öz: Bu çalıșma F3:6 generasyonunda tek bitki döl sıralarının tam ve kısıtlı sulama koșullarında verim, verim bileșenleri ve lif kalite özelliklerinin karșılaștırılması amacıyla Adnan Menderes Üniversitesi Ziraat Fakültesi uygulama alanında tam (\%।00) ve kısıtlı (\%50) sulama koșullarında yürütülmüștür. Tam sulama denemesinde 76 tek bitki, kısıtlı sulama da 68 tek bitki, Carizma, Gloria, Carmen, Claudia ve Elsa kontrol çeșitleri ile birlikte Tesadüf Bloklarında Augmented deneme desenine göre, 4 tekerrürlü olarak sıra arası $70 \mathrm{~cm}$, sıra üzeri $20 \mathrm{~cm}$, sıra uzunluğu $12 \mathrm{~m}$ olacak șekilde ekilmiștir. Kısıtlı sulama (\% 50) koșullarında incelenen tüm özellikler bakımından, tam (\% 100) sulama koșullarında ise kütlü pamuk verimi, lif uzunluğu ve lif kopma dayanıklılığı yönünden genotipik farklılığın önemli olduğu saptanmıștır. Bu çalıșma sonucunda tek bitki döl sıraları; verim ve lif kalite özellikleri bakımından birlikte değerlendirildiğinde; tam sulama koșullarında, Carmen $\times$ Tamcot-22, Carmen $\times$ Nazilli-503, Nazilli-503 $\times$ DPL-90, BA-308 $\times$ Carmen, kısıtlı sulama koșullarında ise Nazilli-503 $\times$ Tamcot-22, Carmen $\times$ Nazilli-503, Nazilli-503 $\times$ Șahin-2000, Carmen $\times$ Tamcot-22, BA-308 $\times$ Nazilli-503, tek bitki döl sıraları ümit verici döl sıraları olarak saptanmıștır.

Anahtar Kelimeler: su stresi, tolerant hatlar

Determination of Yield and Fiber Quality Parameters of Cotton (Gossypium hirsutum L.) Progeny Rows at F3:6 Generation Under Full and Deficit Irrigation Conditions

Abstract: This study was conducted to determine the yield, yield components and fiber quality parameters in a single plant progeny rows at F3:6 generation under the full and deficit irrigation conditions. The experiment was conducted at Adnan Menderes University, Agriculture Faculty in full and deficit conditions.In the full irrigation experiment, 76 single plants, and in the experiment of deficit irrigation 68 single plants were planted. In addition, planting system was the augmented randomized complete block experimental design by performing 4 replications by $70 \mathrm{~cm}$ of row spacing and $12 \mathrm{~m}$ of row length. Under deficit irrigation (\% 50) genotypic variation was found to be significant for all investigated parameters and, under full irrigation (\% 100) condition significant variation was detected for seed cotton yield, fiber length and fiber strength. Based on seed cotton yield and fiber quality parameters of single progeny rows, it was concluded that Carmen $\times$ Tamcot-22, Carmen $\times$ Nazilli-503, Nazilli-503 $\times$ DPL-90, BA-308 $\times$ Carmen single progeny rows are promising in the full irrigation conditions, and Nazilli-503 $\times$ Tamcot-22, Carmen $\times$ Nazilli-503, Nazilli-503 $\times$ Șahin 2000, Carmen $\times$ Tamcot-22, BA-308 $\times$ Nazilli-503 was detected as promising hybrids in the deficit irrigation conditions.

Keywords: water stress, tolerant lines.

\section{GiRiș}

Küresel iklim değișikliği ile birlikte özellikle son yıllarda etkisi daha çok hissedilen kuraklık stresi tüm dünya da bitkisel üretimi tehdit eden faktörlerin bașında gelmektedir. Pamuk (Gossypium hirsutum L.) diğer kültür bitkileri ile karșılaștırıldığında, kuraklığa karșı toleranslı olmasına karșın, bu tolerans kuraklığın süresine ve ortaya çıkıș dönemine göre değișmekle beraber kütlü pamuk verimindeki düșüș oranı \%70-80'e kadar çıkabilmektedir (Krieg, 1997). Aynı aratırıcı, pamuk bitkisinin su stresine karșı en hassas olduğu yetișme periyodunun, taraklanma bașlangıcı ile ilk beyaz çiçeklerin görüldüğü dönem olduğu bildirilmiștir Pamukta çiçeklenme bașlangıcındaki su stresinin büyüme oranını, çiçek ve koza sayısını azalttığı, çiçeklenme periyodunun ikinci yarısındaki su stresinin koza tutumunu, koza sayısını, koza kütlü ağırlığını, çırçır randımanını ve lif uzunluğunu, koza gelișim dönemindeki stresin ise koza kütlü ağırlğı ve olgunlașma süresini etkilediği bildirilmiștir (Marani ve Amirav, 197I). Kuraklık verim ile birlikte lif kalitesini de olumsuz etkilemektedir. Pamuk liflerinin uzamaya bașladığı dönemde ortaya çıkan kuraklığın lif uzunluğu, lif dayanıklılığı ve lif olgunluğunu olumsuz yönde etkilediği birçok araștırıcı tarafından bildirilmiștir (McWilliams, 2004; Mert, 2005; Bașal ve ark., 2009). Kuraklığa dayanıklı çeșit ıslahı ile ilgili yapılan araștırmalar sonucunda; bazı araștırmacılar seleksiyonun sulama (optimum) koșullarında, bazı araștırmacılar ise su stresi altında yapılması gerektiğini belirtmișlerdir. Quisenberry ve ark. (1980) seleksiyonun erken generasyonda ve verimi sınırlamayan optimum veya tam sulama koșullarında yapılması durumunda daha etkin olacağını bildirmișlerdir. Buna karșın Shakoor ve ark. (2010) kuraklığa karșı dayanıklı bitki seleksiyonunun su stresi koșullarında yapılması gerektiğini öne sürmüșlerdir. Stiller ve ark. (2004) ise kurak koșullara dayanıkı genotiplerin belirlenmesinde her iki stratejinin de önemli rol oynayabileceği ve kuraklığa dayanıklı pamuk ıslah çalıșmalarında kullanılan lokasyon sayısının artırılmasını önermișlerdir. $\mathrm{Bu}$ nedenle bu çalıșmada tek bitki seleksiyonu hem tam (\%।00) hem de kısıtlı (\%50) sulama (su stresi) koșullarında yürütülmüștür. Küresel iklim değișikliği ile hava sıcaklıklarının ve CO2 artıșına bağlı olarak bitkisel üretim açısından ortaya çıkacak bir diğer

Sorumlu Yazar: hbasal@adu.edu.tr

Bu çalıșma yüksek lisans tezi ürünü olup, Adnan

Menderes Üniversitesi Bilimsel Araștırma Projeleri

Koordinasyon Birimi tarafindan ZRF-I 602 I no'lu proje

kapsamında desteklenmiștir.

Geliș Tarihi: 8 Ocak 2018

Kabul Tarihi: 31 Mayıs 2018 
sorun yağıș rejiminde görülecek değișikliklerdir. Daha önce yapılan çalıșmalarda da belirtildiği gibi kurak periyodun bașlaması ile birlikte Türkiye'de kuraklıktan en fazla etkilenecek bölgeler arasında pamuk üretimimizin yaklașık \%78'nin gerçekleștirildiği Ege (\%28) ve Güneydoğu (\%50) Anadolu bölgeleri bulunmaktadır (Türkeș, 2008). Dolaysıyla gelecekte ortaya çıkacak kuraklıktan bu bölgelerde en fazla etkilenecek bitki pamuk olacaktır. Bundan dolayı bu çalıșmanın kısa dönemdeki amacı; tek bitki seleksiyon yöntemine uygun olarak seçilen tek bitkilerden olușturulan döl sıralarının F6 generasyonundaki performanslarını karșılaștırmak ve ıslah amacına uygun tek bitkilerin seçilerek bir sonraki generasyona aktarmaktır. Uzun dönemdeki amacı; tam ve kısıtlı sulama koșullarında yüksek verim potansiyeline ve üstün lif kalitesine sahip homozigot hatların geliștirilmesidir.

\section{MATTERYAL ve YÖNTEM}

\section{Materyal}

Bu çalıșmanın materyalini olușturan populasyon, daha önceki çalıșmalar sonucunda kuraklığa tolerant olduğu varsayılan 8 pamuk çeșidi (ST-373, BA-308, Carmen, Nazilli-503, Tamcot Sphinx, Șahin 2000, DPL-90 ve Tamcot-22) yarım diallel melezleme tekniğine uygun olarak 2009 yılında Adnan Menderes Üniversitesi Ziraat Fakültesi Tarla Bitkileri bölümünde yapılan melezleme sonucu elde edilen 28 melez kombinasyonundan olușmuștur. 2010 yılında FI, 2011 yılında F2 generasyonu olușturulmuștur. Aynı yılın sonunda tam (\%।00) ve kısıtlı sulama (su stresi; \%50) koșullarında yetiștirilen F2 generasyonundaki her melez kombinasyonuna ait her bir bitkiden alınan bir kozanın tohumları bulk yapılarak F3 tohumları elde edilmiștir. F3 generasyonu, Adnan Menderes Üniversitesi Ziraat Fakültesi Deneme alanında damlama sulama yönteminin uygulandığı tam ve kısıtlı sulama koșullarında yürütülmüștür. Tam ve kısıtlı sulama koșullarında tek bitki seleksiyonuna F3 generasyonunda bașlanmıștır. Bir sonraki generasyona aktarılacak tek bitkilerin seleksiyonu așamalı olarak yapılmıștır. Birinci așama, tarlada tek bitkilerin seçilmesinde koza sayısı, koza dağılımı, bitki boyu ve bitki tipi gibi özellikler göz önünde tutulmuștur. Daha sonra tek bitkilerin hasadından elde edilen kütlü pamukların çırçırlanması sonucu çırçır randımanları belirlenmiștir. Son olarak da High Volume Instrument (HVI) aletinde belirlenmiș tek bitkilerin lif kalite özellikleri dikkate alınarak tekrar seleksiyon yapılarak bir sonraki generasyona aktarılan tek bitkiler belirlenmiștir. 2014 yılında F4 generasyonu, 2015 yılında F5 generasyonu yetiștirilmiș ve tek bitki seleksiyonuna devam edilmiștir. 2015 yılında yürütülen çalıșma sonucunda; verim komponentleri (koza sayısı, çırçır randımanı ve koza kütlü ağırlığı) ve lif kalite kriterleri ile birlikte değerlendirilmesi sonucunda 76 adet 66 tek bitki tam sulama, 68 adet tek bitki kısıtlı sulama koșullarında seçilmiş ve F6 generasyonuna aktarılarak bu çalıșmanın materyalini olușturmuștur.

\section{Yöntem}

Çalıșma Adnan Menderes Üniversitesi Ziraat Fakültesi uygulama alanında tam (\%100) ve kısıtlı (\%50) sulama koșullarında yürütülmüștür. Tam sulama uygulamasında 76 tek bitki, kısıtlı sulama da 68 tek bitki döl sıraları ve beș adet kontrol çeșit (Carizma, Gloria, Carmen, Claudia, Elsa) ile birlikte 16 Mayıs 2016 tarihinde ekim yapılmıștır. Ekimler Tesadüf Bloklarında Augumented deneme desenine göre, 4 tekerrürlü olarak sıra arası 70 $\mathrm{cm}$, sıra uzunluğu 12 m olacak șekilde deneme mibzeri ile yapılmıștır. Denemeye alınan döl sıraları tekerrürsüz olarak bir sıra șeklinde, kontrol çeșitler ise her blokta tekrarlamalı olarak ekilmiștir. Sıralar ilk çapalama ișleminden sonra seyreltilmiș, ikinci çapayla birlikte tekleme yapılarak sıra üzeri $15-20 \mathrm{~cm}$ olacak șekilde bir sırada 60-65 bitki bırakılmıștır.

Ekimden önce dekara saf olarak $6 \mathrm{~kg}$ azot ve $6 \mathrm{~kg}$ fosfor ( $\mathrm{P}_{2} \mathrm{O}_{5}$ ) içeren 20-20-0 gübresi atılmıștır. Çiçeklenmeden hemen önce birinci sulamanın önüne, amonyum nitrat gübresinden, dekara saf olarak $6 \mathrm{~kg}$ azot, gübre mibzeri ile sıra arasına $5 \mathrm{~cm}$ toprak altına verilmiștir. 2 Haziran ve 28 Haziran tarihleri arasında çapalama, ara ișleme ve seyreltme ișlemi yapılmıștır. Denemenin yürütüldüğü alanda üretim mevsimi boyunca Thrips (Thrips tabaci L.), Beyaz sinek (Bemisia tabaci) ,yaprak piresi (Empoasca decipiens), yaprak biti (Aphis gossypii), kırmızı örümcek (Tetraniycus urticae) ve yeșil kurt (Helicoverpa armigera) zararlılarına karșı ilk ilaçlama 03.06.2016 tarihinde, yine aynı zararlılara karșı ikinci üçüncü, dördüncü ve beșinci ilaçlama I5.06.2016, I2.07.2016, 20.07.2016, 29.07.2016 ve 4.08.2016 tarihlerinde yapılmıștır. Ayrıca 10.08.2016 ve 24.08.2016 da iki kez bitki gelișim düzenleyicisi (Pix) kullanılmıștır. Tüm parsellere hasat öncesi kozaların yaklașık olarak \%70 açtığı dönemde yaprak döktürücü ve koza açtırıcı uygulanmıștır. Kısıtlı sulama uygulanan parsellerin hasadı 16-20.10.2016 tarihinde, tam sulama uygulanan parsellerin hasadı ise 20-31.10.2016 tarihinde yapılmıștır.

Tam (\%।00) ve kısıtlı (\%50) sulama koșulları altında olușturulan denemede damla sulama sistemi kullanılmıștır. Deneme parsellerinin sulanması için gerekli olan sulama suyu, Adnan Menderes Üniversitesi Ziraat Fakültesi içerisinde bulunan yer altı su kaynağından sağlanmıștır. Sulama suyu, bir motopomp yardımıyla rehabilitasyon çalıșmaları yapılan yerdeki kuyudan alınarak $63 \mathrm{~mm}$ dış çaplı kaytanlı PVC borular ile araștırma alanına getirilmiș ve her parselde sıraya tek lateral gelecek șekilde $16 \mathrm{~mm}$ dıș çaplı polietilen (PE) 
lateraller deneme parsellerine serilmiștir. Lateral damla sulama boruları $2 \mathrm{l} / \mathrm{h}$ debili içe geçik damlatıcılı olup damlatıcı aralıkları $25 \mathrm{~cm}$ olarak seçilmiștir. Deneme parsellerinde toprak neminin izlenmesi; gravimetrik yöntemle örneklerin ölçülmesinde, 0-30, 30-60, 60-90 toprak katmanlarından alınan toprak örnekleri daraları alınmıș alimunyum kaplara konularak yaș ağırlıkları tartılmıș, daha sonra etüvlenerek 105 oC de 24 saat kurutulduktan sonra kuru ağırlıkları tekrar tartılmıștır. Böylece toprağın nem içeriği yüzde (\%) olarak hesaplanmıștır. Her sulamadan önce bozulmuș toprak örnekleri, düzenli olarak belirlenen katmanlardan sonda yardımı ile Petersen ve Calvin (1965)'de belirlenen esaslara göre alınmıștır. Tam sulama șartlarında kullanılabilir su miktarı \%50'ye düștüğünde sulamaya bașlanmıștır. Sulama öncesi hem tam sulama hem de kısıtlı sulamanın uygulandığı parsellerden toprak örnekleri alınarak topraktaki nem miktarı hesaplama yöntemiyle belirlenmiștir. Tam sulama uygulanan parsellere belirlenen nem açığının tamamı, kısıtlı sulama parsellerine ise hesaplanan su miktarının yarısı kadar su verilmiștir. Pamuk yetișme mevsiminde tam sulama uygulanan parsellere toplam $592 \mathrm{~mm}$, kısıtlı sulama uygulanan parsellere ise toplam $296 \mathrm{~mm}$ su verilmiștir.

\section{BULGULAR ve TARTIȘMA}

Tam (\%।00) ve kısıtlı sulama (\%50) koșullarında F3:6 generasyonunda incelenen özelliklere ilișkin varyans analiz sonuçları Çizelge I'de verilmiștir. Kısıtlı sulama (\%50) koșullarında incelenen tüm özellikler bakımından, tam (\%।00) sulama koșullarında ise kütlü pamuk verimi, lif uzunluğu ve lif kopma dayanıklılığı yönünden genotipik farklılığın önemli olduğu saptanmıștır.

Çizelge I. Tam ve kısıtlı sulama koșullarında F3:6 generasyonunda incelenen özelliklere ait varyans analiz sonuçları

\begin{tabular}{|c|c|c|c|c|c|c|c|c|c|}
\hline Varyasyon & \multirow[b]{2}{*}{ SD $\neq$} & \multicolumn{4}{|c|}{ Tam sulama $(\%$ I00) } & \multicolumn{4}{|c|}{ Kısıtlı sulama $(\% 50)$} \\
\hline Kaynakları & & BKS & KPV & LU & LKD & BKS & KPV & LU & LKD \\
\hline Tekerrür & 3 & $14.6 * *$ & 1398.01 & 0.3 & 5.4 & 0.8 & 1853.7 & 0.09 & 1.3 \\
\hline Genotip & 4 & 3.1 & $5563.5^{*}$ & $2.4^{*}$ & $34.8^{* *}$ & $8.6^{*}$ & $8589.4^{* *}$ & $2.1^{*}$ & $26.1^{* *}$ \\
\hline Hata & 12 & 1.3 & 1462.4 & 0.5 & 4.6 & 1.7 & 851.7 & 0.5 & 4.1 \\
\hline Genel & 19 & & & & & & & & \\
\hline
\end{tabular}

‡: SD= Serbestlik derecesi, BKS= Bitkide koza sayısı, KPV= Kütlü pamuk verimi, LU= Lif uzunluğu, LKD= Lif kopma dayanıklılı̆̆ı.

*: 0,05 olasılık seviyesinde önemli, **: 0,0 I olasılık seviyesinde önemli.

Tek bitki döl sıralarının tam (\%।00) ve kısıtlı (\%50) sulama koșulları altında incelenen özelliklere ilișkin ortalama değerleri Çizelge 2 ve 3'de verilmiștir. F6 generasyonunda tam sulama koșullarında 76 adet, kısıtlı sulama koșullarında 68 adet tek bitki döl sıraları beș adet kontrol çeșit (Carizma, Gloria, Carmen, Claudia, Elsa) ile birlikte değerlendirilmiștir. Ancak derginin sayfa kısıtlamasından dolayı her sulama koșulunda sadece kütlü pamuk verimi bakımından ilk ve son on sırada yer alan döl sıralarının incelenen özelliklere ait ortalama değerleri verilebilmiștir.

Tam (\%।00) sulama uygulamasında, melez döl sıraları arasında en yüksek koza sayısı değeri $(\mathrm{H}: 70,24.2$ adet/bitki) DPL-90 × Tamcot-22 melez döl sırasında, en düșük koza sayısı değeri $(\mathrm{H}: 35,10.2$ adet/bitki) ise ST$373 \times$ Nazilli-503 melez döl sırasında gözlenmiștir. Çalıșmada kontrol olarak kullanılan pamuk çeșitleri arasında Carmen 14.3 (adet/bitki) koza sayısı ile ilk sırada yer almıștır. İncelenen özelik bakımından en yüksek değere sahip kontrol çeșit ile döl sıraları karșılaștırıldığında, genotipler arasında gözlenen fark önemsiz bulunmuș, 32 adet melez döl sırasının rakamsal olarak kontrol çeșitlerden yüksek değerlere sahip olduğu saptanmıștır (Çizelge 2).

Kısıtlı (\%50) sulama uygulaması altında, melez döl sıralarının bitkide koza sayısı değerlerinin 2।,2 adet/bitki (Nazilli-503 × Șahin 2000, H:58) ile, 8.3 adet/bitki (BA$308 \times$ Carmen, $\mathrm{H}: 25)$ değer aralığında yer aldığı görülmüștür. Kontrol olarak kullanılan çeșitler içerisinde en yüksek koza sayısı (I2.6 adet/bitki) Gloria'da saptanmıștır. İncelenen özelik bakımından en yüksek değere sahip olan kontrol çeșit ile döl sıraları karșılaștırıldığında 23 adet melez döl sırasının kontrol çeșitten daha yüksek koza sayısına sahip olduğu saptanmıștır (Çizelge 3). Bitkide koza sayısı (adet/bitki) bakımından kısıtlı ve tam sulamaya ait genel ortalama değerleri karșılaștırıldığında; kısıtlı sulama koșullarının bitkide koza sayısını \% 9 oranında azalttığı gözlenmiștir (Çizelge 2 ve 3). Bu sonuç, su stresinin bitkide koza sayısını olumsuz etkilediğini bildiren diğer çalıșmalar ile uyum içerisindedir (Mert, 2005; Pettigrew, 2004; Basal ve ark., 2009; Hussein ve ark., 20II).

Tam (\%।00) sulama uygulamasında tek bitki döl sıralarının ortalama kütlü pamuk verim değerleri 662.7 kg/da (Nazilli-503 × DPL-90, H:40) ile 292.2 kg/da (BA$308 \times$ Carmen, H:57) arasında değișmiștir. Kontrol pamuk çeșitler arasında en yüksek verim değeri 534.2 kg/da ile Gloria çeșidinde gözlenmiștir. Hatlar arasında I3 adet melez döl sırasının kütlü pamuk verimi bakımından Gloria çeșidinden daha yüksek verim değerlerine ulaștığı, altı adet hattın $(\mathrm{H}: 40, \mathrm{H}: 53, \mathrm{H}: 30$, $\mathrm{H}: 60, H: 6)$ ise yüksek verim değerleri bakımından ön plana çıktığı gözlenmiștir (Çizelge 2).

Su stresi (\%50 kısıtlı sulama) altında kütlü pamuk verimi bakımından ilk sırada Carmen $\times$ Tamcot-22 (H:66, 644.2 $\mathrm{kg} / \mathrm{da}$ ) tek bitki döl sırası yer alırken, Nazilli-503 $\times$ Tamcot-22 (H:24, I35.8 kg/da) tek bitki döl sırasının son sırada yer aldığı gözlenmiștir. Kısıtlı sulama 
uygulamasında kontrol çeșitlerin kütlü pamuk verim değerleri sırayla Gloria $442.3 \mathrm{~kg} / \mathrm{da}$, Carmen $417 \mathrm{~kg} / \mathrm{da}$, Claudia $386.2 \mathrm{~kg} / \mathrm{da}$, Elsa $362.9 \mathrm{~kg} / \mathrm{da}$, Carizma 323.6 $\mathrm{kg} / \mathrm{da}$ olarak tespit edilmiștir (Çizelge 3). Kütlü pamuk verimi bakımından tek bitki döl sıraları ile en yüksek verim değerine sahip kontrol çeșit (Gloria $442.3 \mathrm{~kg} / \mathrm{da}$ ) karșılaștırıldığında; 18 adet melez döl sırasının verim değerinin kontrol çeșidin verim değerinden daha yüksek ve aradaki farkın da önemli olduğu bulunmuștur. Kısıtlı sulama uygulamasının kütlü pamuk verimini \%।6.6

Çizelge 2. F3:6 generasyonuna ait seçilmiș tek bitki döl sıralarının tam sulama (\%।00) koșullarında incelenen özellikler

bakımından ortalama değerler

\begin{tabular}{|c|c|c|c|c|c|}
\hline Hat no & Melez kombinasyonu & $\begin{array}{l}\text { BKS } \neq \\
\text { (adet/bitki) }\end{array}$ & $\begin{array}{l}\text { KPV } \\
\text { (kg/da) }\end{array}$ & $\begin{array}{l}\text { LU } \\
(\mathrm{mm})\end{array}$ & $\begin{array}{l}\text { LKD } \\
\left(g / \text { tex }^{x}\right)\end{array}$ \\
\hline 40 & Nazilli-503 × DPL-90 & 13.5 & 662.7 & 27.5 & 32.6 \\
\hline 53 & Carmen $\times$ Nazilli-503 & 13.7 & 653.8 & 31.7 & 30.8 \\
\hline 30 & Carmen $\times$ Nazilli-503 & 12.9 & 646.5 & 29.7 & 30.5 \\
\hline 60 & Carmen $\times$ Tamcot- 22 & 17.7 & 645.6 & 29.9 & 29.2 \\
\hline 6 & BA-308 × Carmen & 14.7 & 638.3 & 30.7 & 27.5 \\
\hline 21 & ST-373 × Șahin 2000 & 16.0 & 637.8 & 29.4 & 31.3 \\
\hline 28 & BA-II9 × SJ-U86 & 11.5 & 637.2 & 30.3 & 35.5 \\
\hline 16 & BA-308 $\times$ Carmen & 13.4 & 617.6 & 29.8 & 31.4 \\
\hline 2 & BA-308 × Șahin 2000 & 12.4 & 616.6 & 31.2 & 32.2 \\
\hline 4 & BA-308 × Carmen & 13.3 & 616.3 & 29.4 & 30.2 \\
\hline 75 & ST-373 × Șahin 2000 & 13.2 & 456.0 & 32.0 & 29.9 \\
\hline 62 & Șahin $2000 \times$ Tamcot-22 & I8.1 & 453.6 & 30.3 & 33.4 \\
\hline 14 & DPL-90 × Tamcot-22 & 13.1 & 441.2 & 30.1 & 28.9 \\
\hline 45 & ST-373 × DPL-90 & 10.6 & 437.6 & 29.1 & 38.3 \\
\hline 41 & ST-373 × Șahin 2000 & 14.9 & 435.7 & 34.2 & 33.4 \\
\hline 18 & DPL-90 × Tamcot-22 & 10.4 & 424.5 & 28.9 & 29.7 \\
\hline 12 & ST-373 × Șahin 2000 & 14.4 & 422.8 & 31.4 & 30.6 \\
\hline 47 & Carmen × DPL-90 & 19.7 & 418.9 & 32.4 & 31.6 \\
\hline 3 & ST-373 × Nazilli-503 & 10.8 & $4 \mid 4.4$ & 32.0 & 30.0 \\
\hline 56 & Carmen $\times$ Tamcot- 22 & 12.0 & 391.6 & 31.1 & 32.8 \\
\hline \multicolumn{6}{|c|}{ Kontrol Çeșitler } \\
\hline \multicolumn{2}{|l|}{ Carizma } & 13.0 & 467.0 & 28.9 & 29.6 \\
\hline \multicolumn{2}{|l|}{ Gloria } & 13.8 & 534.2 & 30.9 & 37.4 \\
\hline \multicolumn{2}{|l|}{ Carmen } & 14.3 & 504.7 & 30.2 & 34.9 \\
\hline \multicolumn{2}{|l|}{ Claudia } & 13.9 & 451.4 & 30.7 & 36.2 \\
\hline \multicolumn{2}{|c|}{ Elsa } & 13.1 & 447.9 & 30.0 & 34.6 \\
\hline \multicolumn{2}{|c|}{ Genel Ortalama } & 14.3 & 527.5 & 30.1 & 31.8 \\
\hline \multicolumn{2}{|c|}{ EKÖF0.05 } & Ö.D. & 58.9 & $\mathrm{I} .14$ & 3.29 \\
\hline
\end{tabular}

‡: BKS= Bitkide koza sayısı, KPV= Kütlü pamuk verimi, LU= Lif uzunluğu, LKD= Lif kopma dayanıklılığı. azalttığı tespit edilmiștir (Çizelge 2 ve 3). İki farklı pamuk çeșidi kullanılarak yapılan çalıșmada kısıtlı sulama koșullarında verimin \%16 ve \%28 oranında azaldığı gözlemlenmiștir (Papastylianou ve Argyrokastritis 20l4). Diğer bir çalıșmada sulama suyu seviyesindeki düșüșten dolayı verimde de \%।2 lik bir düșüș tespit edilmiștir (Asadi ve ark., 20II). Bu çalıșmada gözlenen ortalama verim kayıpları daha önce yapılan çalıșmalarla paralellik göstermektedir (Basal ve ark., 2009; Karademir ve ark., 20II). 
ULU B, BAȘAL H

Çizelge 3. F3:6 generasyonuna ait seçilmiș tek bitki döl sıralarının kısıtlı sulama (\%50) koșullarında incelenen özellikler bakımından ortalama değerleri

\begin{tabular}{|c|c|c|c|c|c|}
\hline Hat no & Melez kombinasyonu & $\begin{array}{l}\text { BKS } \neq \\
\text { (adet/bitki) }\end{array}$ & $\begin{array}{l}\text { KPV } \\
(\mathrm{kg} / \mathrm{da})\end{array}$ & $\begin{array}{l}\mathrm{LU} \\
(\mathrm{mm})\end{array}$ & $\begin{array}{l}\text { LKD } \\
\left(g / \text { tex }^{x}\right)\end{array}$ \\
\hline 66 & Carmen $\times$ Tamcot-22 & 13.5 & 644.2 & 29.7 & 33.2 \\
\hline 52 & ST-373 $\times$ Carmen & 12.9 & 621.3 & 29.5 & 36.0 \\
\hline 31 & BA-308 × Nazilli-503 & 16.1 & 619.7 & 29.3 & 30.4 \\
\hline 55 & BA-308 × DPL-90 & 15.1 & 582.0 & 28.7 & 27.6 \\
\hline 48 & Nazilli-503× Tamcot-22 & 15.9 & 578.0 & 26.9 & 29.4 \\
\hline 3 & Carmen $\times$ Nazilli-503 & 18.3 & 542.9 & 28.9 & 33.2 \\
\hline 37 & BA-308 × Nazilli-503 & 16.0 & 542.2 & 30.5 & 29.6 \\
\hline 58 & Nazilli-503 × Șahin 2000 & 21.2 & 539.8 & 27.7 & 27.3 \\
\hline 20 & BA-308 × Nazilli-503 & 14.3 & 533.8 & 33.1 & 30.2 \\
\hline 45 & ST-373 $\times$ Carmen & 15.5 & 531.3 & 28.8 & 32.0 \\
\hline 16 & BA-308 $\times$ Carmen & 11.7 & 344.2 & 28.7 & 34.9 \\
\hline 19 & BA-308 × Șahin 2000 & 10.1 & 340.8 & 32.2 & 29.7 \\
\hline 27 & Șahin $2000 \times$ Tamcot-22 & 12.4 & 330.0 & 29.8 & 30.6 \\
\hline 28 & ST-373×Tamcot Sphinx & 8.6 & 327.6 & 27.9 & 32.1 \\
\hline 47 & $\mathrm{ST}-373 \times \mathrm{BA}-308$ & 9.8 & 312.4 & 29.0 & 33.6 \\
\hline 12 & Tamcot Sphinx $\times$ DPL-90 & 11.6 & 312.0 & 29.4 & 31.4 \\
\hline 32 & ST-373 $\times$ Carmen & 10.6 & 273.0 & 30.8 & 34.3 \\
\hline 29 & BA-308 $\times$ Nazilli-503 & 10.1 & 268.0 & 31.0 & 30.1 \\
\hline 21 & ST-373 × BA-308 & 12.3 & 254.5 & 29.1 & 31.6 \\
\hline 24 & Nazilli-503× Tamcot-22 & 7.1 & 135.8 & 29.9 & 26.1 \\
\hline \multicolumn{6}{|c|}{ Kontrol Çeșitler } \\
\hline \multicolumn{2}{|c|}{ Carizma } & 10.1 & 323.6 & 28.3 & 30.3 \\
\hline \multicolumn{2}{|l|}{ Gloria } & 12.6 & 442.3 & 28.5 & 35.6 \\
\hline \multicolumn{2}{|l|}{ Carmen } & 11.7 & 417.4 & 29.8 & 37.1 \\
\hline \multicolumn{2}{|l|}{ Claudia } & 10.2 & 386.2 & 29.6 & 34.8 \\
\hline \multicolumn{2}{|l|}{ Elsa } & 8.9 & 362.9 & 29.6 & 35.0 \\
\hline \multicolumn{2}{|c|}{ Genel Ortalama } & 13.1 & 439.8 & 29.7 & 37.7 \\
\hline \multicolumn{2}{|c|}{ EKÖF 0.05} & 2.01 & 45.0 & 1.12 & 3.11 \\
\hline
\end{tabular}

‡: BKS= Bitkide koza sayısı, KPV= Kütlü pamuk verimi, LU= Lif uzunluğu, LKD= Lif kopma dayanıklılığı

Tam (\%।00) sulama uygulamasında melez döl sıralarının lif uzunluk değerleri $34.2 \mathrm{~mm}$ (ST-373 × Șahin 2000, $\mathrm{H}: 4 \mathrm{I}$ ) ile $26.9 \mathrm{~mm}$ (GSN-I $2 \times$ Tamcot 22, H:27) arasında değișim göstermiștir. Kontrol çeșitler arasında en yüksek lif uzunluk değeri $30.9 \mathrm{~mm}$ ile Gloria olduğu belirlenmiștir (Çizelge 2). Gloria (30.9 mm) ile melez hatlar arasındaki yapılan karșılaștırılmada 6 adet melez döl sırasının Gloria çeșidinden daha yüksek lif uzunluk değerleri aldığı görülmüștür.

Tek bitki döl sıralarının kısıtlı (\%50) sulama uygulamasında lif uzunluk değerlerine bakıldığında; en yüksek lif uzunluğu $(33.1 \mathrm{~mm})$ BA-308 × Nazilli-503 $(\mathrm{H}: 20)$ melez kombinasyonunda, en düșük lif uzunluğu değeri ise $(26.7 \mathrm{~mm}) \mathrm{ST}-373 \times \mathrm{DPL}-90, \mathrm{H}: 63 \mathrm{melez}$ kombinasyonunda gözlenmiștir. Denemede bulunan kontrol çeșitler arasında Carmen çeșidi $29.8 \mathrm{~mm}$ lif uzunluk değeri ile ilk sırada yer almıștır (Çizelge 3). Kısıtlı (\%50) sulama koșullarında incelenen özellik bakımından kontrol çeșitlerden Carmen $(29.8 \mathrm{~mm})$ ile melez hatlar karșılaștırıldığında; yedi adet melez döl sırasının Carmen çeșidinden daha yüksek değerler aldığı saptanmıștır. Denemede yer alan tek bitki döl sıralarının kısıtlı (\%50) ve tam sulama (\%।00) uygulamaları altından genel ortalama verileri karșılaștırıldığında; kısıtlı sulama uygulamasının lif uzunluğunu \% 1.49 oranında azalttığı saptanmıștır (Çizelge 2 ve 3). Çiçeklenme döneminin bașlangıç așamasındaki su stresinin lif uzunluğuna etkisi olamayabilir, ancak daha sonraki gelișme periyodunda (çiçeklenme bașlangıç döneminden hemen sonraki dönem) ortaya çıkan su stresinin hücre büyümesi üzerine olan mekanik ve fizyolojik etkilerinden dolayı lif uzunluğu değerini olumsuz etkilemektedir (Bradow ve Davidonis, 2000; McWilliams, 2004; Pettigrew, 2004; Balkcom ve ark., 2006; Basal ve ark., 2009; Price,2009; Hussein ve ark., 201 I; Cave, 2013).

Tam (\%100) sulama koșulunda hatların lif kopma dayanıklılık değerleri 39.1 g/teks (DPL-90 × Tamcot-22, $\mathrm{H}:$ I3) ile $25.0 \mathrm{~g} /$ teks (ST-373 $\times$ Nazilli-503, H:I5) 
aralığında değiștiği görülmüștür. Kontrol olarak kullanılan çeșitler arasında en yüksek lif kopma dayanıklılığına sahip çeșidin Gloria (37.4 g/teks) olduğu saptanmıștır. İncelenen özelik bakımından kontrol çeșit Gloria ile döl sıraları arasındaki fark önemsiz bulunmuștur (Çizelge 2). Su stresi (\%50 kısıtlı sulama) altında Carmen $\times$ Nazilli503 (37.4 g/teks, H:59) melez döl sırasının en yüksek değere, Nazilli-503 × Tamcot-22 (26.l g/teks, H:24) melez döl sırasının ise en düșük lif dayanıklılık değerine sahip oldukları saptanmıștır. Kontrol çeșitler arasında ise Carmen 37.1 g/teks ile ilk sırada yer almıștır (Çizelge 3). En yüksek lif kopma dayanıklılık değerine sahip kontrol çeșidi geçen herhangi bir melez döl sırası bulunmamıștır. Yapılan çalıșma sonucunda hatlar genel ortalamaları bakımından karșılaștırıldığında kısıtlı (\%50) sulama uygulamasının lif kopma dayanıklılığını \%0.08 oranında arttırdığı belirlenmiștir (Çizelge 2 ve 3 ). Daha önce yapılan çalıșmalarda farklı sonuçlar elde edilmiștir. Basal ve ark. (2009), Karademir ve ark. (20II), ve Rai (20II) yaptıkları çalıșmalarda su stresinin lif dayanıklılığını olumsuz yönde etkilediğini, Özkara ve Șahin (1993) tarafından yapılan çalıșmada ise lif dayanıklılığında herhangi bir değișim olmadığını, Papastylianou ve ark. (2014) ise lif kopma dayanıklıı̆ının su stresine karșı verdiği tepkilerin düzensiz olduğunu ortaya koymușlardır.

\section{SONUC}

Tam (\%।00) sulama koșullarında tek bitki döl sıraları verim, verim kompenentleri ve lif kalite özellikleri bakımından değerlendirildiğinde; Carmen $\times$ Tamcot-22, $(\mathrm{H}: 60)$, Carmen $\times$ Nazilli-503, $(\mathrm{H}: 30)$, Carmen $\times$ Nazilli503, (H:32), Nazilli-503 × DPL-90, (H:40), BA-308 $\times$ Carmen, (H:3l), melez döl sıralarının öne çıktığı gözlenmiștir.

Kısıtlı (\%50) sulama uygulamasında; Nazilli-503 $\times$ Tamcot-22, (H:4), Carmen $\times$ Nazilli-503, (H:38), Nazilli$503 \times$ Șahin 2000, $(\mathrm{H}: 58)$, Carmen $\times$ Tamcot-22, $(\mathrm{H}: 66)$, BA-308 × Nazilli-503, (H:22), melez döl sıralarının verim ve lif kalite özellikleri bakımından yüksek değerlere sahip oldukları saptanmıștır. Çalıșma sonucunda tam sulama koșullarında seçilen I23 adet, kısıtlı sulama koșullarında seçilen 118 adet tek bitki F3:7 generasyonuna aktarılmış ve 2017 yılında ıslah çalıșmasına devam edilmiștir.

\section{TEŞEKKÜR}

$\mathrm{Bu}$ çalıșma Adnan Menderes Üniversitesi Bilimsel Araștırma Projeleri Koordinasyon Birimi Tarafından Desteklenmiștir. Proje numarası: ZRF-I602I.

\section{KAYNAKLAR}

Asadi R, Kohi N, Tavassoli A (20II) Effect of Irrigation Regime and Method of Strip Irrigation System on Yield, Yield Components and Water Use Efficiency of Cotton Under Drought Stress Conditions of Orzouiyeh Region of Kerman Province in Iran. Scientific Research and Essays 6: 5812-5819.

Balkchom KS, Reeves DW, Shaw JN, Burmester $\mathrm{CH}$, Curtis LM (2006) Cotton Yield and Fiber Quality From Irrigated Tillage Systems in The Tennessee Valley. Agronomy Journal 98: 596-602.
Basal H, Dagdelen N, Unay A, Yılmaz E (2009) Effects of Deficit Drip Irrigation Ratios on Cotton (Gossypium hirsutum L.) Yield and Fiber Quality. Journal of Agronomy and Crop Science 195: 19-29.

Bradow JM, Davidonis, GH (2000) Quantitation of Fiber Quality and The Cotton Production-Processing Interface: A Physiologist's Perspective. Journal of Cotton Science 4: 34-64.

Cave J. (2013) Cotton Lint Yield, Fiber Quality, and Water-Use Efficiency As Influenced by Cultivar and Irrigation Level. Master of Sciences, Texas Tech University, USA.

Hussein F, Janat M, Yakoub A (20II) Assessment of Yield and Water Use Efficiency of Drip Irrigated Cotton (Gossypium hirsutum L.) as Affected by Deficit Irrigation. Turkish Journal of Agriculture and Forestry 35: 61 I-621.

Karademir Ç, Karademir E, Gençer O (20II) Yield and Fiber Quality of FI and F2 Generations of Cotton (Gossypium hirsutum L.) Under Drought Stress Conditions. Bulgarian Journal of Agricultural Science 17: 795-805.

Krieg DR (1997) Genetic and Environmental Factors Affecting Productivity of Cotton. In: Dugger P, Richter DA (eds.), Proceeding Beltwide Cotton Conf., January 7-10 1997. New Orleans, LA, 1347.

Marani A, Amirav A (197I) Effects of Soil Moisture Stress on Two Varieties of Upland Cotton in Israel. Experimental Agriculture 7: 213-224.

McWilliams D (2004) Drought Strategies for Cotton. Cooperative Extension Service Circular 582 College of Agriculture and Home Economics http://www.cahe.nmsu.edu/pubs/circulars (Erișim Tarihi: $15 / 10 / 2011)$.

Mert M (2005) Irrigation of Cotton Cultivars Improves Seed Cotton Yield, Yield Components and Fibre Properties in The Hatay Region, Turkey. Acta Agriculturae Scandinavica B 55: 44-50.

Özkara M, Sahin A (1993) Ege Bölgesinde Farklı Sulama Programlarının Nazilli-84 ve Nazilli-87 Pamuk Çesidinin Verim ve Bazı Kalite Özelliklerine Etkileri. Menemen Araștırma Enst. Md. Yayınları, Genel Yayın No:193, s. 58, Menemen.

Papastylianou P, Argyrokastritis I (2014) Effect of Limited Drip İrrigation Regime on Yield, Yield Components, and Fiber Quality of Cotton Under Mediterranean Conditions. Agricultural Water Management |42:127-I34.

Petersen RG, Calvin LD (1965) Sampling. In: Black, CA (ed.). Methods of Soil Analysis: Physical and Mineralogical Properties, Including Statistics of Measurement and Sampling. Madison, American Society of Agronomy, 54-7I.

Pettigrew WT (2004) Moisture Deficit Effect on Cotton Lint Yield, Yield Components and Boll Distribution. Agronomy Journal 96: 377-383.

Price K (2009). Investigation of Methods to Evaluate Drought Toerance in Cotton. The Degree of Doctor 
of Philosopy. Texas Tech University, Texas Lubbock, USA.

Quisenberry JE, Roark B, Fryrear DW, Kohel RJ (1980) Effectiveness of Selection in Uplan Dcotton in Stres Environments. Crop Science 20: 450 - 453.

Rai E (20II) Mechanism of Drought Tolerance in Cotton-Response of Cotton Cultivars to Irrigation in The Texas High Plains. Master of Science, Texas Tech University. Texas Lubbock, USA.

Shakoor MS, Malik TA, Azhar FM, Saleem MF (2010) Genetics of Agronomic and Fiber Traits in Upland
Cotton Under Drought Stress. International Journal of Agriculture and Biology 12: 495-500.

Stiller WN, Reid PE, Constable GA(2004) Maturity and Leaf Shape as Traits Influencing Cotton Cultivar Adaptation to Dry Land Conditions. Agronomy Journal 96: 656-664.

Türkeș M (2008) Gözlenen İklim Değișiklikleri ve Kuraklık: Nedenleri ve Geleceği. Toplum ve Hekim, 23: 97-I07. 
